\title{
DISTRIBUTION AND SOURCES OF POLYCYCLIC AROMATIC HYDROCARBONS IN MARINE SEDIMENTS OF AREAS AFFECTED BY OIL SPILLS IN BEIBU GULF, CHINA
}

\author{
LU, Z. Q. ${ }^{1,2}-\mathrm{KANG}, \mathrm{B} .{ }^{1}-\mathrm{MA}, \mathrm{L}^{{ }^{*}}{ }^{*}-\mathrm{ZHAO}, \mathrm{X}{ }^{1}$ \\ ${ }^{1}$ College of Fisheries, Jimei University, Xiamen 361021, China \\ ${ }^{2}$ Fujian Provincial Key Laboratory of Marine Fishery Resources and Eco-Environment \\ Xiamen 361021, China \\ ${ }^{3}$ The Third Institute of Oceanography, State Oceanic Administration (SOA) \\ Xiamen 361005, China \\ *Corresponding author \\ e-mail: mali@tio.org.cn; phone: +86-59-2219-5335; fax: +86-59-2219-5335 \\ (Received $18^{\text {th }}$ Oct 2017; accepted $12^{\text {th }}$ Feb 2018)
}

\begin{abstract}
Polycyclic aromatic hydrocarbons (PAHs) were analyzed in marine sediments sampled from an area affected by oil spills in Beibu Gulf, China, in order to determine the distribution and potential sources of these PAHs. The total PAHs concentrations presented a range from 11.30 to $141.56 \mathrm{ng} / \mathrm{g}$ with a mean value of $42.12 \mathrm{ng} / \mathrm{g}$, which were relatively low compared to other bays around the world. The four-ring PAHs predominated in most sediment samples, accounting for an average of $41.25 \%$. Principal component analyses (PCA) with multiple linear regression analysis (MLR) and positive matrix factorization (PMF) were used for PAHs source apportionment. The two receptor models both gave good correlation coefficients between predicted and observed PAHs concentrations $\left(\mathrm{R}^{2}=0.9982\right.$ to 0.9987$)$. Three and five factors were obtained from PCA-MLR and PMF, respectively. One factor was identified by PCA as contributions from mixed sources of fuel combustion and coke production (51.44\%). This factor was differentiated into two factors by PMF as contributions from fuel combustion (20.43\%) and coke production (28.99\%). Another PCA factor was attributed to combined coal combustion and crude oil pollution (35.23\%). PMF also differentiated the factor into two factors, the percentages contributions of which were $23.10 \%$ and $13.27 \%$, respectively. Both models gave comparable contributions from wood combustion (13.34\% and $14.20 \%$, respectively).
\end{abstract}

Keywords: PAHs, marine sediments, principal component analyses, positive matrix factorization, Beibu Gulf

\section{Introduction}

Beibu Gulf, a shallow marginal sea located in the northwestern South China Sea, has an area of $129,300 \mathrm{~km}^{2}$ and an average depth of $38 \mathrm{~m}$. Beibu Gulf is a natural semienclosed bay, surrounded by three provinces of China (Guangdong, Hainan and Guangxi) and Vietnam (Zhang et al., 2014; Gu et al., 2015). With the establishment of the Beibu Gulf Economic Rim and ASEAN-China Free Trade Area (ACFTA), Beibu Gulf has now become an essential economic development area in China. On the other hand, the accelerated industrialization and rapid population growth also consequently leads to increasing pollution in this coastal area (Xia et al., 2011), involving heavy metal (Xia et al., 2011; Gan et al., 2013; Gu et al., 2015) and organic pollutants (Zhang et al., 2014; Li et al., 2014, 2015; Kaiser et al., 2016; Ma et al., 2017).

One of the earliest offshore oil fields in China is located in the southwestern Weizhou Island of Beibu Gulf, and petroleum exploration has been conducted extensively in this shallow shelf sea area since the 1970s (Zhang et al., 2015). About 
$132.5 \mathrm{~km}$ long oil and gas pipelines are laid undersea. The main production facilities including platforms and wells produce a total of approximately 16,000 barrels of crude oil per day (Oil and Gas Journal News, 2016). With the rapid economic growth and the expansion of oil exploration in this area, the risk of oil spills during oil exploitation, storage, transportation, and maritime accidents is increasingly high. According to Bulletin of Marine Environmental Status of Guangxi, the oil spill accidents have occurred approximately every year in Beibu Gulf (The Oceanic Administration of Guangxi, 2008-2014). In August 2008, an oil pipeline undersea in Weizhou oil field was broken and more than $1000 \mathrm{t}$ of crude oil were spilled. Almost $2.5 \mathrm{~km}$ shoreline of Beibu Gulf was contaminated by the leakage of crude oil.

Studies have shown that many components of crude oil have long persistence in marine sediments, such as polycyclic aromatic hydrocarbons (PAHs) (Short et al., 2004; Liu et al., 2013). PAHs are defined as a group of aromatic hydrocarbons with two or more aromatic rings in linear, angular or clustered arrangements, most of which are toxic, carcinogenic and mutagenic. Therefore, the United States Environmental Protection Agency (USEPA) classified 16 PAHs as priority pollutants in the early 1980s (Ramdine et al., 2012). PAHs are common in the marine environment and originate from different emission sources, some of them natural, but mostly related to anthropogenic activities such as fuel combustion, offshore production and oil spills (Cortazar et al., 2008; Fasano et al., 2016). Generally, the source of PAHs can be categorized as petrogenic, pyrogenic or diagenetic (Fang et al., 2007; Pongpiachan et al., 2015). So far, to our best knowledge, no or few studies have examined the impact of oil resource exploration and exploitation on the PAHs levels in marine sediments of Beibu Gulf.

The objective of the current study was to investigate the occurrence, distribution, and composition of 16 priority PAHs in surface marine sediments of Beibu Gulf, and to quantitatively identify the potential sources of these PAHs using PCA-MLR and PMF models. Results from these two receptor models were assessed and compared to improve source apportionment of PAHs.

\section{Materials and methods}

\section{Sample collection}

The sampling campaign was carried out in a series of sites of Beibu Gulf (Fig. 1). The sampling sites were designated as such to cover the oil spill influence areas. Surface sediments were collected using a stainless steel grab sampler and wrapped immediately into aluminum foil and then stored at $-20^{\circ} \mathrm{C}$ until laboratory analysis.

\section{PAHs analysis}

All the sediment samples were freeze-dried for $24 \mathrm{~h}$ in a vacuum freeze drier (Topcon Co., USA) and ground to a fine powder (about $60 \mathrm{mesh}$ ). Approximately $5 \mathrm{~g}$ of sample were extracted with a mixture of n-hexane : acetone $(1: 1)$ in a microwave extraction system (CEM Co., USA) by a method developed and verified by the authors (Zhang et al., 2004; Lu et al., 2005). The extract was collected and transferred to a $250 \mathrm{ml}$ Erlenmeyer flask. After mixed with $1 \mathrm{~g}$ of activated copper powder to remove sulfides, the extract was filtered through a funnel filled with anhydrous sodium sulfate (dried at $440{ }^{\circ} \mathrm{C}$ for $4 \mathrm{~h}$ ), and then reduced to $2 \mathrm{ml}$ by rotary evaporation. The 
concentrated extracts flowed through a glass column filled from top to bottom with $9 \mathrm{~g}$ neutral aluminum oxide, $18 \mathrm{~g}$ silica gel and $2 \mathrm{~g}$ anhydrous sodium sulfate. The column was then eluted with $150 \mathrm{ml}$ mixture of $\mathrm{n}$-hexane : pentane $(1: 1)$. The eluent was reduced by rotary evaporation to a final volume of $2 \mathrm{ml}$ and sealed in an amber vial for later GC-MS analysis.

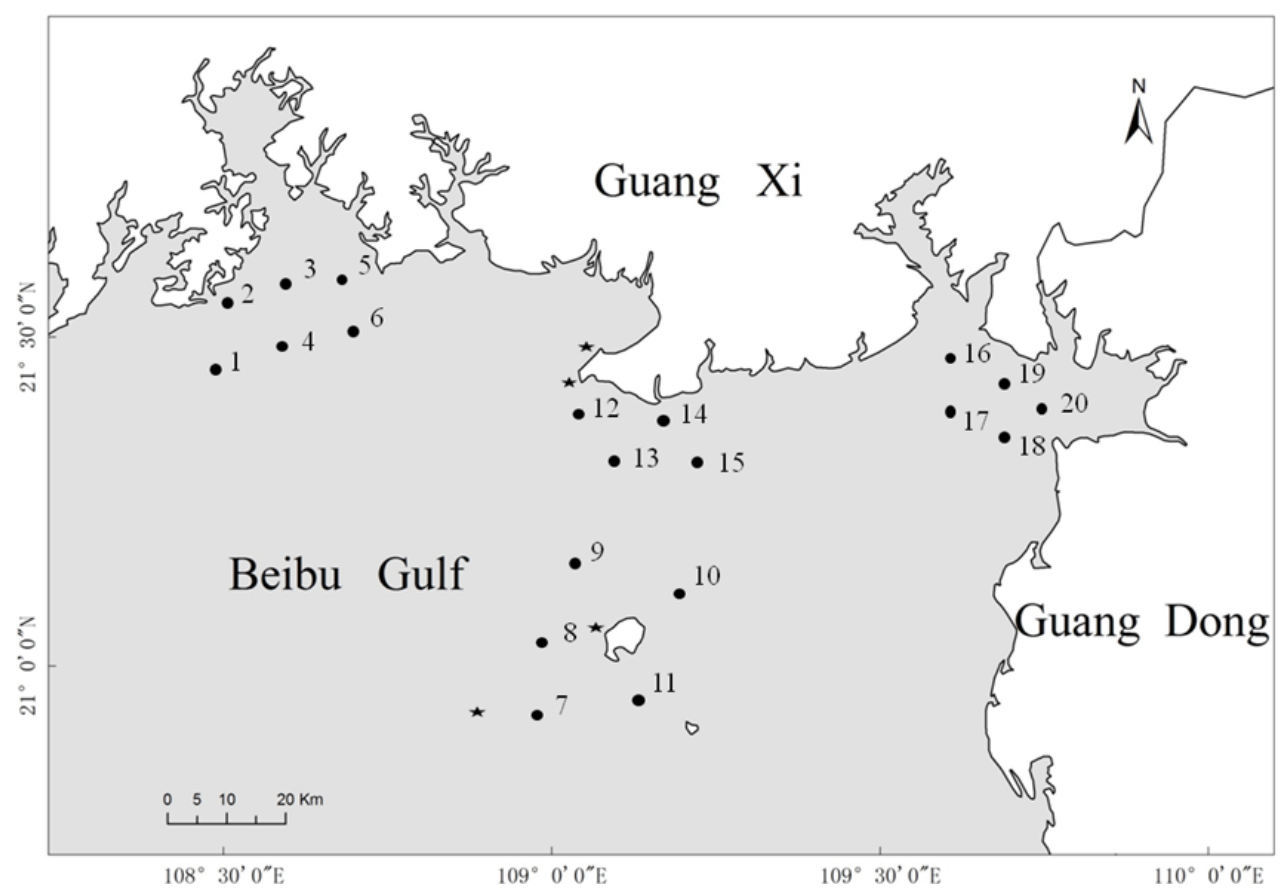

Figure 1. Sampling sites of marine sediments in Beibu Gulf. The black stars indicate the places where oil spill ever occurred during 2008-2014

The PAHs analysis was conducted by a Hewlett-Packard 6890N/5973 gas chromatography coupled with a mass spectrometer (GC/MS). The instrument was operated in selected ion monitoring mode and a $30 \mathrm{~m} \times 0.25 \mathrm{~mm}$ (i.d.) HP-5MS capillary column was used (Agilent Co., USA). The column temperature was programmed from an initial 60 to $150{ }^{\circ} \mathrm{C}$ at $15{ }^{\circ} \mathrm{C} / \mathrm{min}$, from 150 to $220{ }^{\circ} \mathrm{C}$ at $5{ }^{\circ} \mathrm{C}$ /min, from 220 to $300{ }^{\circ} \mathrm{C}$ at $10^{\circ} \mathrm{C} / \mathrm{min}$. The final temperature was held for $10 \mathrm{~min} .16$ PAHs concentrations were determined in all sediment samples including naphthalene (Nap), acenaphthylene (Acpy), acenaphthene (Acp), fluorine (Flu), phenanthrene (Phe), anthracene (Ant), fluoranthene (Flt), pyrene (Pyr), benzo(a)anthracene (BaA), chrysene $(\mathrm{Chr})$, benzo(b)fluoranthene $(\mathrm{BbF})$, benzo(k)fluoranthene $(\mathrm{BkF})$, benzo(a)pyrene $(\mathrm{BaP})$, indeno[1,2,3,cd]pyrene (IcdP), dibenzo(ah)anthracene (DahA), and benzo(ghi)perylene (BghiP).

The standard mixture of 16 PAHs, deuterated PAH surrogate (acenaphthene- $\mathrm{d}_{10}$, phenanthrene- $d_{10}$, chrysene- $d_{12}$ and perylene- $d_{12}$ ) and internal standard (pyrene- $d_{10}$ ) were all obtained from Supelco, Inc. (Supelco, USA). In this study, method blanks, spiked blanks and sample duplicates were all routinely run with field samples. Mean recoveries of acenaphthene- $\mathrm{d}_{10}$, phenanthrene- $\mathrm{d}_{10}$, chrysene- $\mathrm{d}_{12}$ and perylene- $\mathrm{d}_{12}$ were $89.6 \pm 9.5 \%, 97.6 \pm 8.7 \%, 90.3 \pm 8.1 \%$ and $92.1 \pm 7.9 \%$, respectively. The recoveries of spiked samples ranged from $83.8 \%$ to $103.9 \%$. All reported concentrations were given on a dry weight basis and calibrated using surrogate recoveries. 


\section{Source appointment models}

PCA-MLR and PMF, conventional factor analysis receptor models, were both used for source identification of PAHs in sediments by several investigators (Sofowote et al., 2008; Cao et al., 2011; Zhang, 2012; Feng et al., 2014). Before the run of model with the original data, the undetectable values were replaced with random numbers between zero and the limit of detection (Zhang et al., 2008; Liu et al., 2009).

In PCA-MLR model, factor loading and score matrices are calculated by input a set of PAHs concentrations data. The equation $(E q .1)$ is given below:

$$
X=T \times L
$$

where $X$ is the PAHs concentration matrix, $T$ represents the factor score matrix and $L$ represents the factor loading matrix (Zhang et al., 2012). The resulting factor loading matrix can be used to identify the possible source categories. MLR was performed on the factor scores of PCAs for each sample to calculate the percent contribution of the major sources (Larsen and Baker, 2003; Sofowote et al., 2008). The PAH concentrations were Kaiser-normalized and varimax rotation was used as the referred transformation so that loadings values could be clustered around 1 and 0 , making them more physically interpretable. PCA-MLR was performed in this study using SPSS 22.0 software for windows (SPSS Inc., Chicago, IL, USA).

PMF is also a multivariate factor analysis method that calculates source profile and contribution (Paatero, 1997; Zhang et al., 2012). The purpose of the PMF model is to factor the initial $n \times m$ data matrix $X$ (n: number of samples; m: number of species) into the left and right factor matrices $G(n \times p)$ and $F(p \times m)$, as well as the 'residual matrix' $E(n \times m)$ firstly, as follows (Eq. 2):

$$
X=G F+E
$$

In this equation, $G$ is the source contribution matrix, $F$ is the source profile matrix and $E$ is the residual error matrix of the elements $e_{i j}$. Elements of the residual matrix are defined as:

$$
\begin{gathered}
e_{i j}=x_{i j}-\sum_{k=1}^{p} g_{i k} f_{k j} \\
Q=\sum_{i=1}^{m} \sum_{j=1}^{n}\left(\frac{\theta_{i j}}{s_{i j}}\right)^{2}
\end{gathered}
$$

where $g_{i k}$ is the $k_{t h}$ source's contribution to sample $i$, and $f_{k j}$ is the $j$ th element's concentration in source $k, s_{i j}$ represents the uncertainty in the $j$ th species for sample $i$ (Eq.3).

Next, an uncertainty estimate and the residual matrix elements are used to calculate a minimum $Q$ value (Eq.4). The convergent run with the $Q$ value closest to the target $Q$ value was used as the base run. Then 100 bootstrap runs were performed to assess the uncertainty of the factor loadings and factor scores in the base run. PMF analysis in this study was run with the US EPA PMF 3.0 model (US EPA, 2014). 


\section{Results and discussion}

\section{PAHs concentrations and composition}

The total PAHs concentration in marine sediments from Beibu Gulf presented a range of values from 11.30 to $141.56 \mathrm{ng} / \mathrm{g}$, with a mean of $42.12 \mathrm{ng} / \mathrm{g}$ (Table 1). Flu was not detected in all samples. The composition patterns of PAHs were shown in Figure 2. The concentration of PAHs in sediment samples was in the range from 3.97 to $15.56 \mathrm{ng} / \mathrm{g}$ for 2-ring PAHs, from 1.68 to $20.75 \mathrm{ng} / \mathrm{g}$ for 3-ring PAHs, from 4.34 to $62.92 \mathrm{ng} / \mathrm{g}$ for 4-ring PAHs, from 0.26 to $23.21 \mathrm{ng} / \mathrm{g}$ for 5-ring PAHs, and from 0.46 to $22.81 \mathrm{ng} / \mathrm{g}$ for 6-ring PAHs. The mean concentrations were $6.61 \mathrm{ng} / \mathrm{g}$ for 2-ring PAHs, $6.49 \mathrm{ng} / \mathrm{g}$ for 3-ring PAHs, $17.35 \mathrm{ng} / \mathrm{g}$ for 4-ring PAHs, $6.01 \mathrm{ng} / \mathrm{g}$ for 5-ring PAHs, and $5.66 \mathrm{ng} / \mathrm{g}$ for 6-ring PAHs. 4-ring PAHs were abundant at most sampling sites, accounting for $41.25 \%$ of PAHs in marine sediments.

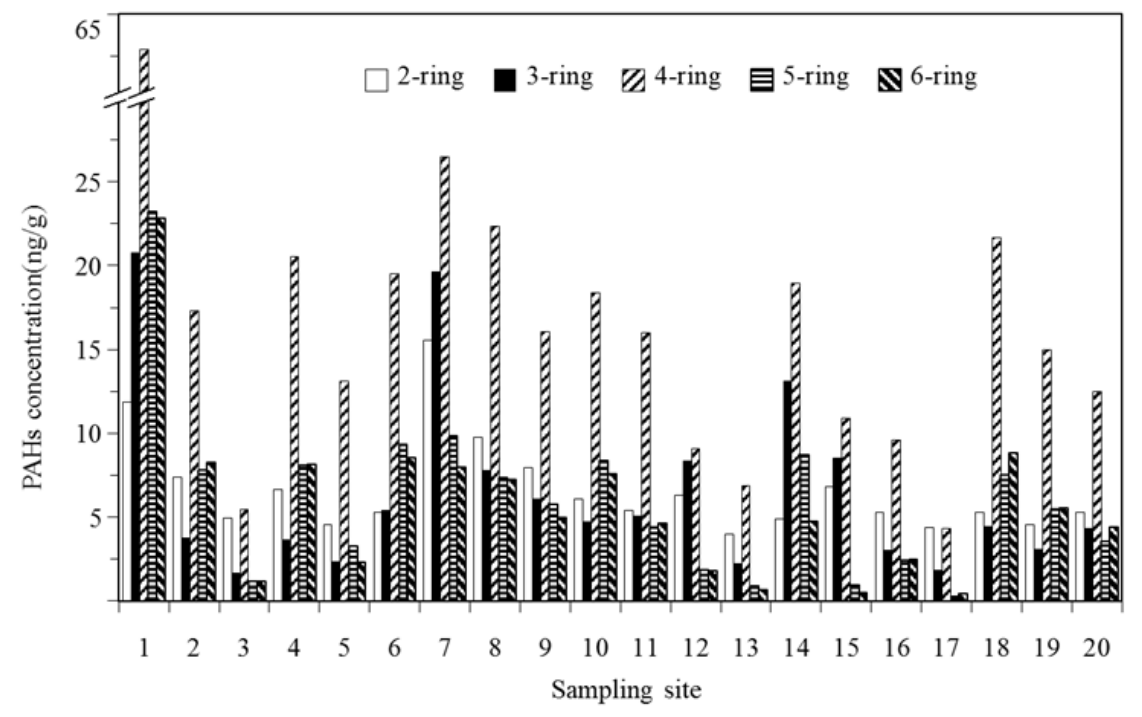

Figure 2. Concentration of 2-, 3-, 4-, 5-, 6-ring PAHs in marine sediments of Beibu Gulf

A preliminary comparison with published data conducted in other bays in China and around the world showed that PAHs concentrations in the marine sediments from Beibu Gulf were at the lower end of the global range. The mean concentration of total PAHs was comparable to the levels in Qinzhou Bay (Li et al., 2015), South China Sea (Liu et al., 2012; Kaiser et al., 2016), the Gulf of Thailand (Boonyatumanond et al., 2006) and Chesapeake Bay (Foster and Wright, 1988), and was lower than those in most other bays in China and around the world. There was no evidence that the PAH levels were significantly increased by oil spill accidents in this area. It could be seen from Figure 3 that a positive relationship was found between total PAH concentrations and total organic carbon (TOC) content $(\mathrm{r}=0.644)$. The similar correlations had been reported by many researchers, and indicated that TOC was a crucial factor for determining the sorption and sequestration of PAHs on sediment (Wang et al., 2001; Sun et al., 2009; Huang et al., 2012). The low concentrations of PAHs in sediments might also be due to low TOC contents $(0.17-1.23 \%$, mean $0.56 \%)$. It was believed that the environmental fate and behavior of hydrophobic organic compounds was ultimately determined by the physico-chemical properties of each compound and sediment. 
Table 1. Concentrations of individual PAHs $(\mathrm{ng} / \mathrm{g})$ and TOC $(\%)$ in marine sediments of Beibu Gulf

\begin{tabular}{|c|c|c|c|c|c|c|c|c|c|c|c|c|c|c|c|c|c|}
\hline Site & Nap & Acpy & Acp & Phe & Ant & Flt & Pyr & $\mathbf{B a A}$ & Chr & $\mathbf{B b F}$ & BkF & BaP & IcdP & DahA & BghiP & $\sum$ PAHs & TOC \\
\hline 1 & 11.87 & 35 & ND & 19.99 & 0.41 & 31.85 & 20.74 & 7.99 & 2.34 & 9.65 & 5.91 & 3.60 & 10.33 & 4.06 & 12.48 & 141.56 & 1.14 \\
\hline 2 & 7.36 & 20 & NDD & 3.23 & 0.33 & 6.50 & 6.51 & 2.99 & & 4.86 & ND & 1.68 & 3.73 & 1.26 & 4.50 & 44.44 & 0.47 \\
\hline 3 & 4.94 & & & 1.44 & & 1.70 & .78 & 0.78 & & 0.48 & 0.38 & 0.29 & .49 & ND & 0.72 & 4.43 & 0.36 \\
\hline 4 & 6.62 & 18 & ND & 3.14 & 0.35 & 8.99 & 7.21 & 3.23 & .09 & 3.80 & 1.59 & 1.52 & 3.77 & 1.17 & 4.41 & 47.06 & 0.62 \\
\hline 5 & 4.55 & 12 & ND & 2.06 & 0.18 & 5.55 & 4.91 & 1.88 & & 1.47 & 1.00 & 0.82 & 0.91 & ND & 1.43 & 25.62 & 0.60 \\
\hline 6 & 5.31 & & ND & 4.91 & 0.36 & 8.36 & 6.81 & 3.23 & & 4.30 & 2.27 & 1.57 & 82 & 1.20 & 4.74 & 3.12 & 0.51 \\
\hline 7 & 15.56 & 67 & 2.94 & & 0. & 8.96 & 13.16 & 3.42 & 97 & .52 & 3.02 & 1.12 & 3.76 & 1.17 & 4.24 & 79.49 & 0.92 \\
\hline 8 & 76 & & ND & 6.99 & 46 & 8.96 & .73 & 2.95 & 73 & 4.04 & 2.36 & 0.94 & 17 & ND & .05 & 4.45 & 0.79 \\
\hline 9 & 7.96 & 0.22 & ND & 5.58 & 0.29 & 6.14 & 7.37 & 1.99 & 0.54 & 2.59 & 1.91 & 0.64 & 2.22 & 0.61 & 2.78 & 40.84 & 0.52 \\
\hline 10 & 6.29 & 38 & ND & 7.50 & 0.46 & 2.50 & 5.13 & 1.04 & 0.45 & 0.74 & 0.62 & 0.49 & 0.74 & ND & 1.03 & 27.37 & 0.27 \\
\hline 11 & 3.97 & & ND & & & 1.82 & 4.31 & & & & & 21 & .27 & ND & 0.42 & 14.68 & 0.16 \\
\hline 12 & 5.39 & 0.23 & ND & 4.40 & 0.40 & 7.68 & 5.44 & 2.30 & 0.59 & 2.53 & 1.26 & 0.64 & 2.02 & ND & 2.63 & 35.50 & 0.78 \\
\hline 13 & 4.89 & & 2.67 & & & 7.90 & 5.16 & 3.73 & & 3.18 & 1.92 & 2.25 & 2.25 & 1.36 & 2.53 & .47 & 0.29 \\
\hline 14 & 6.07 & .23 & ND & 4.02 & 0.46 & 8.03 & 5.51 & 4.10 & 0.77 & 3.75 & 2.23 & 0.95 & 3.56 & 1.42 & 4.03 & 45.12 & 0.85 \\
\hline 15 & 6.81 & 0.13 & ND & 8.37 & ND & 3.36 & 6.93 & 0.49 & 0.10 & ND & 0.94 & ND & ND & ND & 0.49 & 27.63 & 0.27 \\
\hline 16 & 5.31 & 19 & ND & 2.62 & 0.22 & 3.81 & 4.04 & 1.27 & 0.49 & 1.13 & 0.69 & 0.59 & 1.07 & ND & 1.40 & 22.83 & 0.25 \\
\hline 17 & 4.39 & 0.12 & ND & 1.67 & 0.06 & 1.56 & 2.33 & 0.32 & 0.13 & 0.16 & ND & 0.10 & 0.15 & ND & 0.31 & 11.30 & 0.17 \\
\hline 18 & 5.28 & 0.20 & ND & 3.96 & 0.28 & 10.11 & 7.82 & 2.84 & 0.92 & 2.90 & 2.16 & 1.43 & 4.18 & 1.05 & 4.67 & 47.79 & 0.46 \\
\hline 19 & 4.58 & 0.21 & ND & 2.67 & 0.20 & 6.84 & 5.58 & 1.88 & 0.66 & 2.24 & 1.39 & 0.99 & 2.50 & 0.86 & 3.05 & 33.63 & 1.23 \\
\hline 20 & 5.29 & 0.20 & ND & 3.90 & 0.23 & 4.39 & 5.73 & 1.86 & 0.50 & 1.38 & 0.94 & 0.74 & 1.98 & 0.52 & 2.44 & 30.09 & 0.48 \\
\hline
\end{tabular}

${ }^{*}$ ND: not detected (below the detection limit)

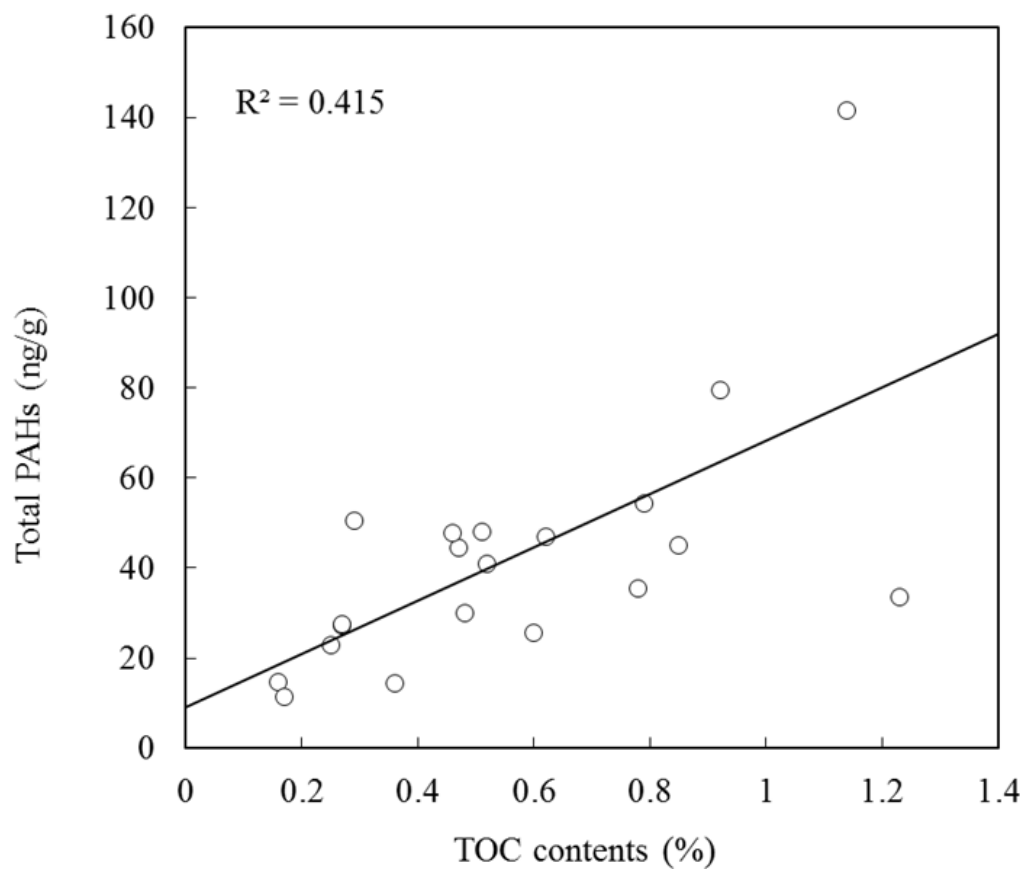

Figure 3. Relation between total PAHs concentrations and TOC contents in marine sediments of Beibu Gulf 


\section{Sources identification by isomer ratios}

Each source generated a characteristic PAH pattern, therefore, analysis of the composition of these mixtures allows assessment of PAH origins (Oros and Ross, 2005). Diagnostic ratios provided only qualitative information about the contribution of various sources with regards to PAH contaminations (Wang et al., 2010). In the present study, the isomer ratios of Flt/(Flt+Pyr) and $\mathrm{BaA} /(\mathrm{BaA}+\mathrm{Chr})$ were calculated to classify the possible sources of PAHs. For Flt/(Flt+Pyr) and $\mathrm{BaA} /(\mathrm{BaA}+\mathrm{Chr})$, the ratios below 0.4 and 0.2 suggest petrogenic origins, whereas the ratios above 0.5 and 0.35 indicate combustion origins (Yunker et al., 2002; Tobiszewski and Namieśnik, 2012). The ratio of Flt/(Flt+Pyr) ranged from 0.30 to 0.61 and the ratio of $\mathrm{BaA} /(\mathrm{BaA}+\mathrm{Chr})$ ranged from 0.63 to 0.84 (Fig. 4). The plot of the two ratios suggested primary contributions from mixed combustion sources. In general, a quantitative proportion of sources of PAHs cannot be given by molecular diagnostic ratios. Therefore, two mathematical models will be used for PAH source appointment in the following sections.

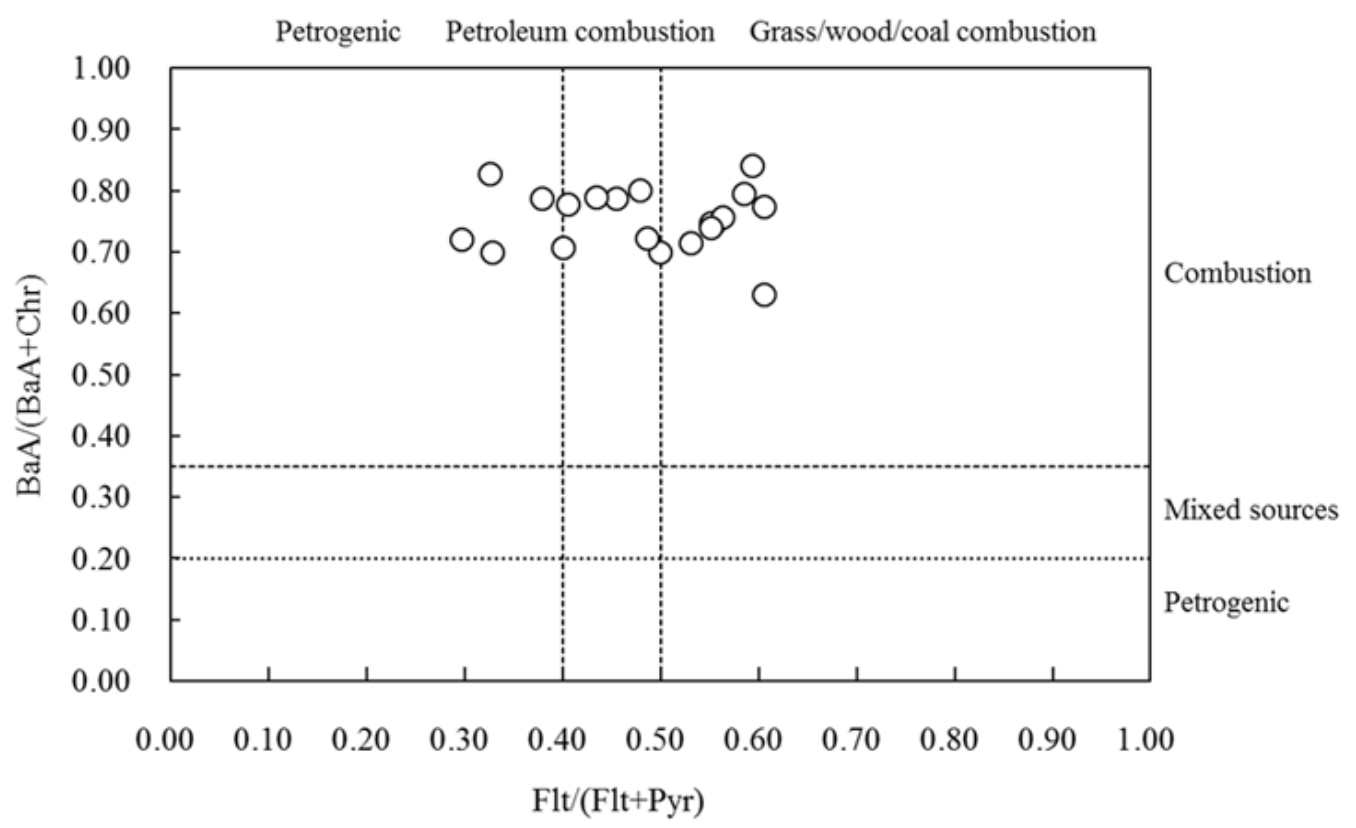

Figure 4. Source analysis of PAHs through plot for the ratios of Flt/(Flt+Pyr) vs. $B a A /(B a A+C h r)$

\section{Source apportionments by PCA-MLR}

In most cases, it was necessary for the control of PAH contamination to obtain more detailed information about the source apportionment (Li et al., 2012). PCA with MLR was considered to be a more suitable tool for further determining the possible PAH sources apportionment, where the model used the linear transformation to choose principal components and represented the total variability of the original PAHs data in a minimum number of factors. (Larsen and Baker, 2003; Sofowote et al., 2008; Li et al., 2012). In this study, PCA resulted in three factors accounting for $93.8 \%$ of the total variability. The rotated component matrix of PAHs in marine sediments from Beibu Gulf was presented in Table 2. 
The first factor, responsible for $54.0 \%$ of the total variance, was heavily weighted by high-ring PAHs including BaP, BghiP, IcdP, BaA, DahA, Flt, BbF, Chr and BkF. IcdP and BghiP were related to the diesel and gasoline engines emission, respectively (Liao et al., 2011). Preponderance of $\mathrm{BaP}, \mathrm{BaA}, \mathrm{BbF}, \mathrm{BkF}$ and $\mathrm{Chr}$ had been related to coke production emissions (Zhang et al., 2012). So, Factor 1 appeared to be related to a combined source of fuel (gasoline and diesel) combustion and coke production. The second factor, contributing to $20.7 \%$ of the total variability, was predominately composed of Nap, Phe and Pyr. Nap constituted a significant fraction of crude oils and petroleum products (Yang, 2000). Phe and Pyr were predominant in coal combustion generated PAHs. Thus, it was tentatively inferred that this factor reflected the complex origins of coal combustion and crude oil pollution. The third factor, accounting for $19.1 \%$ of the total variation, was highly loaded on Acpy, Acp and Ant. Acpy and Ant predominated PAH compounds emitted during wood combustion (Khalili et al., 1995).

Table 2. The rotated component matrix of PAHs in marine sediments of Beibu Gulf

\begin{tabular}{c|c|c|c}
\hline \multirow{2}{*}{} & \multicolumn{3}{|c}{ Component $^{\mathbf{a}}$} \\
\cline { 2 - 4 } Nap & PC1 & PC2 & PC3 \\
Acpy & 0.255 & $\mathbf{0 . 8 7 0}$ & 0.322 \\
Acp & 0.127 & 0.543 & $\mathbf{0 . 8 0 3}$ \\
Phe & -0.044 & 0.225 & $\mathbf{0 . 9 1 1}$ \\
Ant & 0.477 & $\mathbf{0 . 7 2 7}$ & 0.377 \\
Flt & 0.411 & 0.032 & $\mathbf{0 . 8 3 3}$ \\
Pyr & $\mathbf{0 . 8 9 8}$ & 0.402 & 0.007 \\
Chr & 0.677 & $\mathbf{0 . 7 1 9}$ & 0.084 \\
BaA & $\mathbf{0 . 8 5 3}$ & -0.001 & 0.478 \\
BbF & $\mathbf{0 . 9 2 1}$ & 0.267 & 0.232 \\
BkF & $\mathbf{0 . 8 9 2}$ & 0.337 & 0.180 \\
BaP & $\mathbf{0 . 7 5 6}$ & 0.538 & 0.156 \\
IcdP & $\mathbf{0 . 9 3 9}$ & 0.079 & 0.284 \\
DahA & $\mathbf{0 . 9 2 2}$ & 0.350 & 0.049 \\
BghiP & $\mathbf{0 . 9 1 2}$ & 0.249 & 0.132 \\
Percent of variance & $\mathbf{0 . 9 2 3}$ & 0.365 & 0.012 \\
\hline
\end{tabular}

${ }^{\text {a }}$ Rotation method: Varimax with Kaiser normalization

${ }^{\mathrm{b}}$ Loading values exceeding 0.7 are highlighted in bold face

Hence, Factor 3 was reflective of PAH source from wood combustion.

MLR analysis of the PCA factor score was performed to obtain the mass distribution of the three sources to the total PAH load in each sediment samples. The coefficients $\left(B_{\mathrm{i}}\right)$ of three factor scores were determined by the MLR analysis with a stipulated minimum 95\% confidence limit. The MLR equation (Eq.5) for determining the standard deviate of the SumPAH values was: 


$$
\widehat{Z}_{\text {SumPAH }}=0.806 t_{1}+0.552 t_{2}+0.209 t_{3}
$$

The percentage contributions to the mean of the three factors could be calculated as follows (Eq.6):

$$
i(\%)=100 \times\left(B_{i} / \Sigma B_{i}\right)
$$

The percentages contributions were $51.44 \%$ for $t_{1}$ (attributed to mixed source of fuel combustion and coke production), $35.23 \%$ for $t_{2}$ (coal combustion and crude oil pollution), and $13.34 \%$ for $t_{3}$ (wood combustion), respectively. According to the isomer ratios analysis above, a combined combustion source was the primary source of the PAHs in most of samples. Thus, the two analyses of PAH sources were in good agreement.

\section{Source apportionments by PMF}

The five factors solution provided the most reasonable explanation of the source profile. The PMF model generated the following equation (Eq.7):

$$
y_{\text {SumPAH }}=9.401 G_{1}+5.782 G_{2}+11.753 G_{3}+8.317 G_{4}+5.394 G_{5}
$$

The PMF factor profiles (F matrix) of PAHs from Beibu Gulf marine sediments were listed in Table 3. Factor 1 accounted for $23.10 \%$ of all factors contribution, and was heavily loaded on Phe and Pyr, also received moderate loading from Flt. Phe, Flt and Pyr were predominant in coal combustion signals. So Factor 1 was interpreted as reflecting the contribution of coal combustion. Factor 2 was dominated by Acpy, Acp and Ant. Acpy and Ant was the dominant PAHs in the wood combustion. Thus, Factor 2 notionally reflected wood combustion. The percentage contribution of this factor was $14.20 \%$. Factor 3 accounted for $28.99 \%$ of all factors contribution, was highly loaded on Flt, Chr, BaA, BkF, BaP and DahA. Preponderance of BaP, BaA, BbF, BkF and Chr had been related to coke oven emissions. Thus, Factor 3 was identified as a coke production source. Factor 4 was classified as fuel combustion emission based on loadings of BkF, IcdP and BghiP. The higher level of BkF relative to other PAHs was indicative of diesel engine emission; IcdP and BghiP had also been related to diesel and gasoline engine emissions (Liu et al., 2009). Therefore, Factor 4 was selected to represent the fuel combustion, and the percentage contribution was $20.43 \%$. Factor 5 was only highly loaded on Nap and percentage contribution was $13.27 \%$. Nap was believed as a major fraction of crude oils and suggested that this factor was indicative of crude oil pollution.

\section{Comparison of two receptor models}

There was an excellent correlation between measured and predicted total PAHs values by the receptor models $\left(\mathrm{R}^{2}=0.9982\right.$ to 0.9987$)$, indicating that most predicted total PAH concentrations were close to the measured concentrations (Fig. 5). These two factor analysis methods were very effective for quantifying source contributions and differentiating the source profiles. Before running the analysis, no information about the number, characteristics or types of sources impacting the environment was needed to input the models. 
Table 3. PMF factor profiles of PAHs in marine sediments from Beibu Gulf

\begin{tabular}{c|c|c|c|c|c}
\hline Compound & Factor 1 & Factor 2 & Factor 3 & Factor 4 & Factor 5 \\
\hline Nap & 2.364 & 1.245 & 0.000 & 0.132 & $\mathbf{2 . 8 6 3}$ \\
Acpy & 0.063 & $\mathbf{0 . 1 0 7}$ & 0.006 & 0.000 & 0.037 \\
Acp & 0.037 & $\mathbf{0 . 4 9 5}$ & 0.000 & 0.000 & 0.000 \\
Phe & $\mathbf{2 . 6 1 0}$ & 1.650 & 1.264 & 0.000 & 0.125 \\
Ant & 0.005 & $\mathbf{0 . 1 8 4}$ & 0.047 & 0.000 & 0.047 \\
Flt & 1.342 & 0.183 & $\mathbf{3 . 2 3 1}$ & 1.318 & 1.125 \\
Pyr & $\mathbf{2 . 7 9 1}$ & 0.108 & 1.251 & 0.517 & 2.213 \\
Chr & 0.000 & 0.235 & $\mathbf{0 . 2 9 3}$ & 0.195 & 0.006 \\
BaA & 0.000 & 0.525 & $\mathbf{0 . 9 1 2}$ & 0.801 & 0.133 \\
BbF & 0.030 & 0.399 & 0.926 & $\mathbf{1 . 2 9 9}$ & 0.069 \\
BkF & 0.336 & 0.211 & $\mathbf{0 . 6 4 2}$ & 0.175 & 0.189 \\
BaP & 0.037 & 0.154 & $\mathbf{0 . 3 9 5}$ & 0.365 & 0.000 \\
IcdP & 0.207 & 0.041 & 1.004 & $\mathbf{1 . 2 0 8}$ & 0.094 \\
DahA & 0.091 & 0.085 & $\mathbf{0 . 4 1 0}$ & 0.271 & 0.000 \\
BghiP & 0.312 & 0.000 & 1.195 & $\mathbf{1 . 3 5 4}$ & 0.238 \\
Estimated source & coke & Wood & Coal & fuel & oil \\
Percentage contribution & $28.99 \%$ & $14.20 \%$ & $23.10 \%$ & $20.43 \%$ & $13.27 \%$ \\
\hline
\end{tabular}
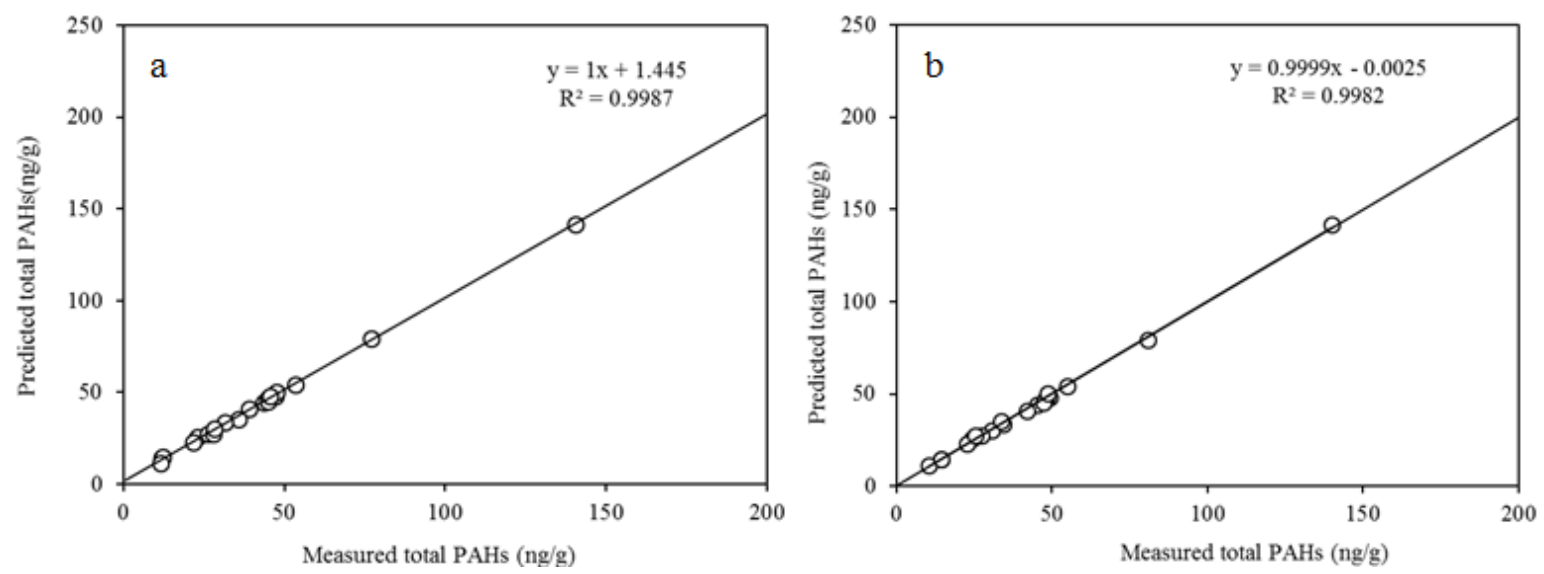

Figure 5. Correlation between measured and predicted total PAHs values by PMF (a) and $P C A-M L R(b)$

Furthermore, both receptor models gave comparable results for $\mathrm{PAH}$ source contributions. The analysis results of PMF for source apportionment were more comprehensive and interpretable than PCA-MLR. Comparable mean contributions from wood combustion sources to marine sediments of Beibu Gulf were obtained from PCAMLR and PMF (13.34\% vs 14.20\%). The PAH contribution attributed to a mixed combustion source classified by PCA-MLR (51.44\%) was close to the sum of coke 
production and fuel combustion $(49.42 \%)$, which were differentiated as two separate factors by PMF (28.99\% and 20.43\%, respectively). The second PCA factor $(35.23 \%$ ) was attributed to a mixed source of coal combustion and crude oil pollution, which was also distinguished by PMF (23.10\% and $13.27 \%$, respectively).

\section{Conclusions}

Marine sediments of Beibu Gulf contained low levels of anthropogenic PAHs compared to other bays worldwide. This indicated that PAHs in sediment resulted from historical accumulation of these compounds and were not significantly increased by oil spill accidents. The results from two receptor models (PCA-MLR and PMF) were compared to quantitatively identify that $\mathrm{PAH}$ sources were mainly originated from coke production (28.99\%), coal, fuel and wood combustion $(23.10 \%, 20.43 \%$ and $13.34-$ $14.20 \%$ ) as well as crude oil pollution (13.27\%). Results obtained in this study could be helpful to evaluate PAH contamination levels in surface sediments of Beibu Gulf, and to provide useful information for protecting marine resources and human health in this region. Further assessment of the potential ecological risks associated with PAHs in seawater, sediments and marine organisms is necessary. Long-term monitoring should be undertaken in order to detect new contamination from the oil exploration and exploitation activities in this area.

Acknowledgements. This work was supported by the Nature Science Foundation of Fujian (No. 2015J01169), the commonweal project from the State Oceanic Administration of China (No.201505027) and the open project from Fujian Provincial Key Laboratory of Marine Fishery Resources and Ecoenvironment.

\section{REFERENCES}

[1] Boonyatumanond, R., Wattayakorn, G., Togo, A., Takada, H. (2006): Distribution and origins of polycyclic aromatic hydrocarbons (PAHs) in riverine, estuarine, and marine sediments in Thailand. - Marine Pollution Bulletin 52(8): 942-956.

[2] Cao, Q., Wang, H., Chen, G. (2011): Source apportionment of PAHs using two mathematical models for mangrove sediments in Shantou coastal zone, China. - Estuaries and Coasts 34(5): 950-960.

[3] Cortazar, E., Bartolomé, L., Arrasate, S., Usobiaga, A., Raposo, J. C., Zuloaga, O., Etxebarria, N. (2008): Distribution and bioaccumulation of PAHs in the UNESCO protected natural reserve of Urdaibai, Bay of Biscay. - Chemosphere 72(10): 1467-1474.

[4] Fang, M. D., Hsieh, P. C., Ko, F. C., Baker, J. E., Lee, C. L. (2007): Sources and distribution of polycyclic aromatic hydrocarbons in the sediments of Kaoping river and submarine canyon system, Taiwan. - Marine Pollution Bulletin 54(8): 1179-1189.

[5] Fasano, E., Yebra-Pimentel, I., Martínez-Carballo, E., Simal-Gándara, J. (2016): Profiling, distribution and levels of carcinogenic polycyclic aromatic hydrocarbons in traditional smoked plant and animal foods. - Food Control 59: 581-590.

[6] Feng, J., Li, X., Guo, W., Liu, S., Ren, X., Sun, J. (2014): Potential source apportionment of polycyclic aromatic hydrocarbons in surface sediments from the middle and lower reaches of the Yellow River, China. - Environmental Science and Pollution Research 21(19): 11447-11456. 
[7] Foster, G. D., Wright, D. A. (1988): Unsubstituted polynuclear aromatic hydrocarbons in sediments, clams, and clam worms from Chesapeake Bay. - Marine Pollution Bulletin 19(9): 459-465.

[8] Gan, H., Lin, J., Liang, K., Xia, Z. (2013): Selected trace metals (As, Cd and Hg) distribution and contamination in the coastal wetland sediment of the northern Beibu Gulf, South China Sea. - Marine Pollution Bulletin 66(1): 252-258.

[9] Gu, Y. G., Lin, Q., Yu, Z. L., Wang, X. N., Ke, C. L., Ning, J. J. (2015): Speciation and risk of heavy metals in sediments and human health implications of heavy metals in edible nekton in Beibu Gulf, China: A case study of Qinzhou Bay. - Marine Pollution Bulletin 101(2): 852-859.

[10] Huang, W., Wang, Z., Yan, W. (2012): Distribution and sources of polycyclic aromatic hydrocarbons (PAHs) in sediments from Zhanjiang Bay and Leizhou Bay, South China. Marine Pollution Bulletin 64(9): 1962-1969.

[11] Kaiser, D., Schulz-Bull, D. E., Waniek, J. J. (2016): Profiles and inventories of organic pollutants in sediments from the central Beibu Gulf and its coastal mangroves. Chemosphere 153: 39-47.

[12] Khalili, N. R., Scheff, P. A., Holsen, T. M. (1995): PAH source fingerprints for coke ovens, diesel and, gasoline engines, highway tunnels, and wood combustion emissions. Atmospheric Environment 29(4): 533-542.

[13] Larsen, R. K., Baker, J. E. (2003): Source apportionment of polycyclic aromatic hydrocarbons in the urban atmosphere: a comparison of three methods. - Environmental Science \& Technology 37(9): 1873-1881.

[14] Li, B., Feng, C., Li, X., Chen, Y., Niu, J., Shen, Z. (2012): Spatial distribution and source apportionment of PAHs in surficial sediments of the Yangtze Estuary, China. - Marine Pollution Bulletin 64(3): 636-643.

[15] Li, P., Wang, Y., Huang, W., Yao, H., Xue, B., Xu, Y. (2014): Sixty-year sedimentary record of DDTs, HCHs, CHLs and endosulfan from emerging development gulfs: a case study in the Beibu Gulf, South China Sea. - Bulletin of Environmental Contamination and Toxicology 92(1): 23-29.

[16] Li, P., Xue, R., Wang, Y., Zhang, R., Zhang, G. (2015): Influence of anthropogenic activities on PAHs in sediments in a significant gulf of low-latitude developing regions, the Beibu Gulf, South China Sea: distribution, sources, inventory and probability risk. Marine Pollution Bulletin 90(1): 218-226.

[17] Liao, S. L, Lang, Y. H., Wang, Y. S. (2011): Distribution and sources of PAHs in soil from Liaohe Estuarine Wetland. - Environmental Science 32(4): 1094-1100 (in Chinese).

[18] Liu, L. Y., Wang, J. Z., Wei, G. L., Guan, Y. F., Zeng, E. Y. (2012): Polycyclic aromatic hydrocarbons (PAHs) in continental shelf sediment of China: implications for anthropogenic influences on coastal marine environment. - Environmental Pollution 167: $155-162$.

[19] Liu, X., Jia, H., Wang, L., Qi, H., Ma, W., Hong, W., Guo, J., Yang, M., Sun, Ye., Li, Y. F. (2013): Characterization of polycyclic aromatic hydrocarbons in concurrently monitored surface seawater and sediment along Dalian coast after oil spill. Ecotoxicology and Environmental Safety 90: 151-156.

[20] Liu, Y., Chen, L., Huang, Q. H., Li, W. Y., Tang, Y. J., Zhao, J. F. (2009): Source apportionment of polycyclic aromatic hydrocarbons (PAHs) in surface sediments of the Huangpu River, Shanghai, China. - Science of the Total Environment 407(8): 29312938.

[21] Lu, Z. Q., Zheng, W. J., Ma, L. (2005): Bioconcentration of polycyclic aromatic hydrocarbons in roots of three mangrove species in Jiulong River Estuary. - Journal of Environmental Sciences 17(2): 285-289.

[22] Ma, L., Lu, Z. Q., Zhang, Y. B., Yang, S. Y. (2017): Distribution and sources apportionment of polycyclic aromatic hydrocarbons in the edible bivalves and 
sipunculida from coastal areas of Beibu Gulf, China. - Applied Ecology \& Environmental Research 15(3): 1211-1225.

[23] Oil and Gas Journal News. (2016): CNOOC begins production from two more Beibu Gulf fields. - http://www.ogj.com/articles/2016/02/cnooc-begins-production-from-twomore-beibu-gulf-fields.html.

[24] Oros, D. R., Ross, J. R. (2005): Polycyclic aromatic hydrocarbons in bivalves from the San Francisco estuary: spatial distributions, temporal trends, and sources (1993-2001). Marine Environmental Research 60(4): 466-488.

[25] Paatero, P. (1997): Least squares formulation of robust non-negative factor analysis. Chemometrics and Intelligent Laboratory Systems 37(1): 23-35.

[26] Pongpiachan, S., Hattayanone, M., Choochuay, C., Mekmok, R., Wuttijak, N., Ketratanakul, A. (2015): Enhanced $\mathrm{PM}_{10}$ bounded PAHs from shipping emissions. Atmospheric Environment 108: 13-19.

[27] Ramdine, G., Fichet, D., Louis, M., Lemoine, S. (2012): Polycyclic aromatic hydrocarbons (PAHs) in surface sediment and oysters from mangrove of Guadeloupe: Levels, bioavailability, and effects. - Ecotoxicology and Environmental Safety 79: 8089.

[28] Short, J. W., Lindeberg, M. R., Harris, P. M., Maselko, J. M., Pella, J. J., Rice, S. D. (2004): Estimate of oil persisting on the beaches of Prince William Sound 12 years after the Exxon Valdez oil spill. - Environmental Science \& Technology 38(1): 19-25.

[29] Sofowote, U. M., McCarry, B. E., Marvin, C. H. (2008): Source apportionment of PAH in Hamilton Harbour suspended sediments: comparison of two factor analysis methods. Environmental Science \&Technology 42(16): 6007-6014.

[30] Sun, J. H., Wang, G. L., Chai, Y., Zhang, G., Li, J., Feng, J. (2009): Distribution of polycyclic aromatic hydrocarbons (PAHs) in Henan reach of the Yellow River, Middle China. - Ecotoxicology and Environmental Safety 72(5): 1614-1624.

[31] The Oceanic Administration of Guangxi. (2008-2014): Bulletin of Marine Environmental Status of Guangxi (2008-2014). - http://www.gxoa.gov.cn/gxhyj_haiyanggongbao.

[32] Tobiszewski, M., Namieśnik, J. (2012): PAH diagnostic ratios for the identification of pollution emission sources. - Environmental Pollution 162: 110-119.

[33] US EPA (2014): EPA positive matrix factorization (PMF) 5.0 fundamentals \& user guide. - https://www.epa.gov/air-research/epa-positive-matrix-factorization-50-fundamentalsand-user-guide.

[34] Wang, H. S., Cheng, Z., Liang, P., Shao, D. D., Kang, Y., Wu, S. C., Wong, C. K. C., Wong, M. H. (2010): Characterization of PAHs in surface sediments of aquaculture farms around the Pearl River Delta. - Ecotoxicology and Environmental Safety 73(5): 900-906.

[35] Wang, X. C., Zhang, Y. X., Chen, R. F. (2001): Distribution and partitioning of polycyclic aromatic hydrocarbons (PAHs) in different size fractions in sediments from Boston Harbor, United States. - Marine Pollution Bulletin 42: 1139-1149.

[36] Xia, P., Meng, X. W., Yin, P., Cao, Z. M., Wang, X. Q. (2011): Eighty-year sedimentary record of heavy metal inputs in the intertidal sediments from the Nanliu River estuary, Beibu Gulf of South China Sea. - Environmental Pollution 159: 92-99.

[37] Yang, G. P. (2000): Polycyclic aromatic hydrocarbons in the sediments of the South China Sea. - Environmental Pollution 108(2): 163-171.

[38] Yunker, M. B., Macdonald, R. W., Vingarzan, R., Mitchell, R. H., Goyette, D., Sylvestre, S. (2002): PAHs in the Fraser River basin: a critical appraisal of PAH ratios as indicators of PAH source and composition. - Organic Geochemistry 33(4): 489-515.

[39] Zhang, G., Jin, L., Lan, L., Zhao, Z. (2015): Analysis of the orderly distribution of oil and gas fields in China based on the theory of co-control of source and heat. - Natural Gas Industry B 2(1): 49-76.

[40] Zhang, J., Cai, L., Yuan, D., Chen, M. (2004): Distribution and sources of polynuclear aromatic hydrocarbons in mangrove surficial sediments of Deep Bay, China. - Marine Pollution Bulletin 49(5): 479-486. 
[41] Zhang, J., Li, Y., Wang, Y., Zhang, Y., Zhang, D., Zhang, R., Zhang, G. (2014): Spatial distribution and ecological risk of polychlorinated biphenyls in sediments from Qinzhou Bay, Beibu Gulf of South China. - Marine Pollution Bulletin 80(1): 338-343.

[42] Zhang, W., Zhang, S., Wan, C., Yue, D., Ye, Y., Wang, X. (2008): Source diagnostics of polycyclic aromatic hydrocarbons in urban road runoff, dust, rain and canopy throughfall. - Environmental Pollution 153(3): 594-601.

[43] Zhang, Y., Guo, C. S., Xu, J., Tian, Y. Z., Shi, G. L., Feng, Y. C. (2012): Potential source contributions and risk assessment of PAHs in sediments from Taihu Lake, China: comparison of three receptor models. - Water Research 46(9): 3065-3073. 